\title{
THE REFUSAL OF TRANSCENDENCE: CAUSE OF BANKRUPTCY OF POSTMODERN PEDAGOGY. FOR A FORMATIVE-ANTHROPOLOGICAL PROGRAM PLACED "BEYOND" AND ABOVE THE CULTURE OF RESPECT
}

\begin{abstract}
$\dagger$ Gurie Georgiu*
Motto: The most powerful civilization that man has ever known, the European one, can destroy the earth, but ... it is incapable of training a teenager.

Andre Malraux
\end{abstract}

\begin{abstract}
This study includes three subdivisions: 1. For a realistic diagnosis of postmodern pedagogy. The limits of the non-theistic didactic approaches of life: this section contains an inventory of postmodern pedagogical errors, as they are found in Jean Sevillia's vision, inventory followed by the prophylaxis proposed by secular anthropology. The section ends with an Orthodox sentence: immanent anthropology cannot settle the crisis which hits a culture and pedagogy without metaphysics. Orthodoxy suggests another approach: deep within a "culture of respect" there should be a "culture of love"; 2. For a transcendentally articulated education. How do we "lower" the issue of meaning in the daily formative-educative approach? This section is based on the finding that post-Enlightenment pedagogy evacuated the transcendent from culture and pedagogy, shaping the ideal portrait of the teacher, in the Orthodox vision; 3. The concept of secularism: disinterest in the ultimate sense of things or granting of freedom? The last section outlines a possible pastoral profile of the concept of secularism. The excursion includes an interpretation for the pastoral-didactic use, of the film Superman returns.
\end{abstract}

Keywords: the refusal of transcendence, positive secularism, culture of respect, obsession of comfort, holistic pedagogical breathing, ultra-earthly horizons, mystical competent mentor.

* Bishop of Deva and Hunedoara, PhD Assistant Professor, "1 Decembrie 1918" University of Alba Iulia, Romania. 


\section{For a realistic diagnosis of postmodern pedagogy. The limits of} the non-theistic didactic approaches of life (and of human existence in general)

Why is the process of education, of training young people, increasingly difficult and the final products are less and less satisfactory? Why is the exercise of their vocation generating more and more dissatisfaction for trainers and teachers? Why are the terrorists of the Western world - in general - young and very young, subjects who had the experience of Western pedagogy, being integrated into mainstream education, but who subsequently became capable of criminal acts? Instead of integration, people slipped into a spiral of de-socialization, the victims becoming the exponents of a nihilist counterculture, followers of present demolition and future refusal.

Europe has chosen - from the 50s of the last century - for the "massification" of higher education (university became a mass phenomenon) and for long-term schooling. It has done so with the tacit hope that this will dissolve mediocrity and the elite class will acquire numerical hegemony in society. The result was not the one anticipated, though. Mediocrity has extended to all social floors, cancerising the entire social fabric. People have come to treat their neighbours as an object of consumption. The purpose of the others is to guarantee my happiness! - This is the new anthropological doctrine of the masses.

Where were society, culture, education wrong? Jean Sevillia gives us an inventory of pedagogical errors, from his perspective:

a) The destruction of the traditional family by turning it into a sum of individuals i.e., a new public "family" portrait which is no longer a social institution, but a personal affair, in the service of the individual;

b) Sclerotizing the culture of effort and waiving any penalties for comfort and laziness;

c) Spreading, through the media, the belief that life does not have anything absolute, and as a consequence, the public dogma is: 
there are no more taboos either regarding the social goods, or the people (therefore in certain entourages to kill someone is part of an initiatory path that guarantees the growth of prestige and respect within the gang);

d) The subtle invitation to violence through visual familiarization through the media (poisoning with violent images, waves of blood, bodies torn to pieces influence behaviour: intense scenes lower the thresholds of perception of the other's suffering).

What kind of prophylaxis does secular anthropology propose? The explosion of violence and delinquency in the Western world (with its epicentre in France, the "champion" country of secularism) is the product of a dismantling society; the disintegration factors are: the individualistic mentality (1), the hedonistic spirit (2), the decline of authority and rejection of rules (3), family breakdown (4), school crisis (5), loss of guiding marks (6), moral relativism (7). The same secular anthropology suggests restoring "the culture of respect" as a saving and corrective program: civics (1), responsibility and observance of citizens' duties (2), discipline (3), submission to the common law (4), security (5). But - we ask ourselves - how are these positive requirements to be implemented on a barren, infertile or even "radioactive" soil?

Therefore, the Christian finding is this: secular anthropology is incapable of solving the deep crisis of a culture devoid of metaphysics. Life has something absolute, inviolable, sacred, from a different world; only respecting and recognizing this sacredness will we activate the sensors to receive realities beyond matter, the only ones that can give content and meaning to matter. "The meaning of this life is not in it, but beyond it!" - It is the truth that religion has been propagating for millennia. Only by living in harmony with the universe and with the entire existence will we get to intercept the other levels of reality, will we be able to access the other existential floors which are supernatural and unseen by earthly eyes, but in a natural normal continuation of this world. Orthodoxy suggests another terminology: deep within the "culture of respect" there should be a "culture of love", the energy from beyond the world which can change the face of this earth and can make us sensitive to 
the realities of the world beyond. Without it, we remain prisoners of the material world and any access to metaphysical realities is denied. Without it, any cohesion of our society is impossible.

2. For a transcendentally articulated education. How do we "lower" the issue of meaning in the daily formative-educational approach?

When we address the issue of God, we, in fact, address the issue of meaning. Of the total full meaning of life, and of the subsumed, segmented, partial meanings which each of us discover (or proclaim) along our biographical trajectory. The pedagogy of the whole Western secular and post-Enlightenment space ran away with "heroic" consistency - from this complex issue because it did not (and does not) have ultra-earthly horizons. It evacuated the transcendent from culture and pedagogy. But only finding a convincing answer to the question of meaning can motivate, can boost, can impart dynamism in a world paralyzed by materialism. Which is the psycho-cultural profile of the western young teenager who is a "candidate" to suicide, but first programmed to kill? In the subconscious of this young person there is the firm belief that this life is not worth living, for various reasons. It's an emotional, rationally grounded conviction.

For us, in Eastern Europe, it is thus appropriate to ask: are we transmitting the young the conviction that this life is worth living? What makes it beautiful and savoury? Is it sufficient? It is a catalyst of energy and can it build a constellation of uplifting and exciting purposes? The answer is positive only if we include the transcendent into our logic and into our investigative approach.

The Orthodox tradition speaks less of pedagogy and more about apprenticeship, i.e. about the presence of the apprentice in the vicinity of his confessor, presence not only intellectually enriching, but also emotionally. Raising the young must be accompanied by people generating love, balance, peace; true training is not theoretical training, but a transfer of emotions from an experienced mentor to an apprentice eager for progress and knowledge. 
Pedagogy cannot be simplified to the level of collections of educational intervention techniques, of teaching methods with guaranteed effects, but it is an art you can practise, which mandatorily has holistic breath: the trainer must have a consistent vision of man, world and life, must know the ideal profile of the man he wants to update. This is precisely what the pedagogy specific to the postmodern public space is missing: it is a juxtaposition of pieces of knowledge; it is a mosaic map of disparate sciences (which are sometimes quarrelling) which lacks an overall universally accepted vision.

The true purpose of education - from the Orthodox point of view - is the full and harmonious development of man, identifying their own talents and charismas, formulating their own existential project, finding their place in the world, strengthening the belief that everyone has an unrepeatable, unmistakable, attractive, useful, absolutely necessary, non-substitutable identity in view of the overall world panorama, history and God's heavenly plan. So the trainer has no reason to focus attention on generating information and theoretical knowledge to the beneficiary (which may or may not be accepted). The ultimate and highest goal of education is the integral, holistic and complete development of the existentially wellintegrated human being. This ultimate goal is not necessarily a functional and practical one, but a - once reached - it ensures the fluid and loose evolution towards an adequate motivated and motivating professional training.

Unfortunately, exactly this ultimate and maximum goal of education has been cut off in postmodern culture. It has become practical, it has professionalized, allowing itself to be confiscated by certain technical skills; it has become instruction; in other words, the intermediate, partial (though necessary and useful) goals have swollen, excluding entirely the existence of a higher purpose, fully accomplishing, of metaphysical amplitude and ontological anchoring. That is why Giovanni Papini is so sarcastic and ruthless, describing education as "emasculating, standardizing and homogenizing manipulation" and demanding categorically the closing down of public schools: "In schools we witness the 
systematic seizure of children in dusty rooms, dominated by the most unnatural physical immobility, immobility combined with a sclerosis of the spirit, forced to repeat what is said, instead of being allowed to do research, investigate by itself; there, the disastrous efforts of teachers to teach others, through imbecile methods, a lot of unnecessary things are hegemonic: school has become a temple of systematic annihilation of personality, of originality, and extirpation of any initiative, under the standardizing control of school curricula. Those who have covered all stages of school education and are not utterly stupid can be happy that they got off easy!"

Growth to adulthood and independence, the acquisition of authentic freedom, involve constant, rhythmic, well-articulated interaction with the mentor and can hardly be simplified to a passive absorption of theoretical knowledge. It involves a predisposition towards internalization, not a voluptuous hunger for externalization, exhibit and slipping from the inside to the outside. The real duty of the teacher is to awaken the apprentice's thirst for knowledge, to help the apprentice learn how to help themselves, to give practice to the apprentice into learning to assume the responsibility and burden of their own training.

The trainer is thus not a transmitter of information, a generator of theoretical knowledge, but a savoury presence emanating energies and impressing with enriching emotions, their formative approach going far beyond the pedagogical intervention techniques specific to the lay universe, being perfectly legitimate and useful: analysis, synthesis, implementation, etc. Bloom's revised taxonomy speaks of different levels of processing knowledge, articulated in six points:

a) updating: activation of the assimilated contents from memory;

b) understanding: demonstration of understanding the assimilated knowledge or knowledge systems and conferring personal significance to the knowledge acquired;

c) application: identification and testing the applicability of knowledge, algorithms and actionable plans; 
d) analysis: identifying traits and relationships and existing principles;

e) evaluation: critical reference to knowledge;

f) creation: generating new ideas, creative production in different manners.

All these are found spontaneously in the pedagogical approach of the spiritual master.

\section{The concept of secularism: disinterest in the ultimate sense of things or granting of freedom?}

The term secularism is often found in the pedagogical field. It should not in any way inhibit the answer to certain absolutely legitimate questions, demonstrating the strength of the recipients of education to address the essential: Does life have meaning? What happens after death?

Oppressive cultures understood aggressively and applied reductively the notion of secularism in all areas of life. But we can speak of positive secularism, open to the great questions, which recognizes the right of every man to live and manifest their faith inclusively in the area of education and to transmit it to future generations. Faith is a generator of positive emotions, of spreading love, a factor setting networks of harmony and understanding in society.

On the other hand, the concept of secularism is very important from the point of view of Christian faith, because it has the notion of freedom as its ontological axis, concept postulated as the supreme value of the Gospels along with the one of love (Christianity has always proclaimed these two values as supreme values). Secularism is a form of freedom, freedom to believe or not to believe, freedom to practise a religion or not, freedom to change one's religion or to keep the one you were born into.

In pedagogy, positive secularism implies an enriching openness towards the colossal potential of psycho-emotional training of the Christian religion, dominant in the Euro-Atlantic space. Positive healthy secularism in the pedagogical environment means an 
attitude that considers religion a formative educational opportunity and not a threat. This means promoting a fertile dialogue between pedagogy and the dominant religion (or religions) in the space where the pedagogical approach is exercised, in order to facilitate absorption of spiritual vision, and not its rejection. In a world obsessed with comfort and material wealth, the interest in discovering the overall meaning of things and in knowing our own identity survives forcibly; or, those who can come to meet this interest are people of faith, religious community leaders who know God, went through a journey of spiritual training and can be models on the path to authentic spiritual development. The world - though it does not realize it - desperately needs them.

It is a priority of social life and postmodern pedagogy to reduce the anti-religious and anti-Christian character of secularism left over from the militant communist atheism. Positive secularism does not see religion as a threat or danger, but as a valuable and enriching opportunity.

Excursion: A pseudo pedagogical model, functional at the medium and sub-medium level: Superman - a postmodern messiah. The contemporary "correction" of Christ through Superman-like "formatting". How would people want the Messiah to be?

The Judeo-Christian archetype of Messiah can be found in many films (mostly US ones) because it is a symbol deeply rooted in the collective Western imaginary (whose origin is Christian). A paradigm of reference in this regard, explicitly messianic, is the film Superman Returns. Superman ("the primordial") is created by two American artists of Hebrew origin, in 1934, years of economic crisis, marked by a desperate need for heroes, saviours. The plot is simple: Superman - born on a planet that is long gone - was raised by adoptive parents on the Kent farm in Kansas. Young Kal-El is given a new name, Clark Kent, but, although he grew up among people, he is not one of them. Under Earth's yellow sun he can do things that 
ordinary people cannot even dream of; to coexist with them, he must lead a double life: a simple man, but on the other hand, secretly transforming into the Man of Steel, who steps in forcefully when evil tries to dominate. But now the world's crises have gone unresolved for five years as Superman disappeared in a mysterious way. Without him, the rate of crimes in the city of Metropolis has skyrocketed, and this without counting the future destructive actions of Lex Luthor, who came out of prison with the intention of using Superman's technological secrets, to get fame and personal gain.

We can find many parallels between Superman and Christ. Radically different are, however, their ways to save the world: this reveals certain disappointment of today's world towards the salvation brought by Christ, a Superman-like rescue being preferred, at least at an unconscious level: external, instant and immanent. While Superman sacrifices himself as a hero, after He saves the world, Jesus dies in everyone's contempt (subject to rogues); the whole world accompanies Superman in his death drama (it is a planetary event!), while just a group of women watch over Jesus (mothers are included in both cases). Bankruptcy is part of Jesus' experience, and the salvation that He promised never arrived, meaning that the world remained the same, full of malice and misery.

How can a "messiah" leave the world as he found it? But the essence of the Christian doctrine is this: Jesus conquers death dying ("...trampling down death by death"), destroys evil accepting it, turns man into God, making Himself man up to the end (and bearing the last consequences). But what kind of salvation is this? Should the true saviour not extirpate evil, eliminate the wicked? Christ accepts them and then becomes their victim!

Here is, instead, Superman's profile: the biggest enemy of crime, a wandering knight permanently defeating evil. Instead, the Saviour takes evil upon Himself, accepts it; does not tear it, does not uproot it, does not exclude it, but takes it upon Himself, bears it. He does this with confidence in God the Father, Who, though He is the source of all goodness, the source of Goodness and Love, He allows evil to exist! He does not give the disciples permanent superpowers, nor invincible weapons. Don't we love the portrait of Superman - the 
evictor of evil from history, more than that of the gentle and permissive Christ? Are we to defeat terrorism by exterminating the terrorists or by trying to solve the problem which is the origin of their actions?

Dealing with helplessness, pain and death is the path that will decide who is truly a man. He will subsequently have the power to become God. What pedagogical model do we propose to children, then? Everything has a dose of Prometheism, i.e. all models have a drop of Prometheus. And the villain of the film, Lex Luthor, and Superman are the different sides of the same coin, depicting the human desire to be like God. But how is He really? Christ is an antiPrometheus, is a God who becomes man, is a superman who gives up his powers to share the suffering condition of man, to then make men similar to God through love.

\section{***}

In conclusion, we can say that true education strengthens young people's inclination to love and opens their appetite for renewing and ennobling emotional experiences. Accepting transcendence in pedagogy opens new horizons capable of expanding consistently and infinitely the ontological potential of the recipient of education. The social repercussions will be abundant and persuasive, generating collective peace and fortified individual and collective identities, mentally robust and imposing from the existentialanthropological point of view.

\section{References}

1. Editoriale: La presenza del crocifisso nelle scuole, în rev. La Civilta' Cattolica, 2004, II (quaderno 3695 - 5 giugno), p. 417-424.

2. Idem, Il cristianesimo $e^{\prime}$ il destino dell'Europa, în rev. La Civilta' Cattolica, 2004, III (quaderno 3699/3700 - 7-21 agosto), pp. 209-219.

3. Guerello, Francesco S. I., I religiosi el missione educativa nela scuola, în rev. La Civilta' Cattolica, 2003, I (quaderno 3665 - 1 marzo), p. 516-524.

4. Mucci, Giandomenico S. I., La febbre dello sport e il nichilismo, în rev. La Civilta' Cattolica, 2005, III (quaderno 3722 - 16 luglio), p. 161-165. 
5. Idem, La religione nella societa' dell'ideologia: M. Gauchet, în rev. La Civilta' Cattolica, 2005, IV (quaderno 3730 - 19 novembre), p. 330-337.

6. Giuseppe de Rosa S. I., Nicolas Sarkozy e la laicita' positiva, în rev. La Civilta' Cattolica, 2008, I (quaderno 3782 - 19 gennaio) p. 174-176.

7. Reguzzoni, Mario S. I., Globalizzazione e educazione, în rev. La Civilta' Cattolica, 2006, II (quaderno 3739 - 1 aprile), p. 59-65.

8. Sale, Giovanni S.I., La scuola nel dibattito alla costituente, în rev. La Civilta' Cattolica, 2005, II, (quaderno 3717 - 7 maggio), p. 231-244.

9. Sevillia, Jean, Corectitudinea morală. Căutăm cu disperare valori, Editura Humanitas, București, 2009, p. 196.

10. Spadaro, Antonio S. I., Non e' il molto sapere che sazia e soddisfa! Il modello pedagogico ignaziano, în rev. La Civilta' Cattolica, 2007, I (quaderno 3760 - 17 febbraio), p. 324-337.

11. Zito, Giuseppe S. I., Il ritorno di Superman. Di quale salvatore ha bisogno il mondo?, în rev. La Civilta' Cattolica, 2006, III (quaderno 3750 - 16 settembre), p. 506-510. 